\title{
ANALISIS PENGARUH PENGANGGARAN PARTISIPATIF, INFORMASI ASIMETRIS, DAN MOTIVASI KARYAWAN TERHADAP SENJANGAN ANGGARAN PADA BANK BUMN DI INDONESIA
}

\author{
Antonius Bimo Rentor ${ }^{(1)}$, \\ Universitas Kristen Maranatha \\ antoniusbimo22@gmail.com \\ Yenni Carolina ${ }^{(2)}$, \\ Universitas Kristen Maranatha \\ yenzcarolina@gmail.com
}

\begin{abstract}
Some issues on budget are appear in many forms at banking industry especially in Indonesia. One of the issues that related to the budget is marked by efforts of the employee to create space in budgeting. This issue called as a budgetary slack. The purpose of this research is to analyze various factors that influence budgetary slack. These factors include participatory budgeting, asymmetric information, and employee motivation. The data collection techniques used in this research were questionnaires. Meanwhile, the analytical method used in this study is PLS 'Partial Least Square'. The conclusion of the study is that the participatory budgeting variable has no effect on the budgetary slack variable. Meanwhile, asymmetric information variables and employee motivation variables were each stated to influence budgetary slack variables.
\end{abstract}

Keywords: Budgetary Slack, Participatory Budgeting, Asymmetric Information, and Employee Motivation.

\section{PENDAHULUAN}

Mulyani (2019) selaku Menteri

Keuangan Negara Republik Indonesia menyatakan bahwa anggaran pada dasarnya memiliki peranan penting dalam mengelola perekonomian dalam suatu kelompok maupun organisasi. Nasution (2019) selaku Menteri Koordinator Bidang Perekonomian menambahkan bahwa anggaran sebagai instrument fiskal tidak hanya penting untuk pemerintahan melainkan penting bagi swasta maupun BUMN. Nasution (2019) juga mengatakan bahwa pentingnya anggaran ini berkaitan dengan upaya mendukung pengembangan infrastruktur yang dapat memajukan organisasi yang melakukan penganggaran. Namun Baharuddin (2019) selaku Kepala Pusat Penerangan Kementerian Dalam Negeri menyatakan bahwa permasalahan dalam proses penyusunan anggaran merupakan salah satu permasalahan yang cukup rumit dan sensitif sehingga 
memerlukan penanganan yang baik dan terstruktur. Anggaran yang terdapat pada setiap kesatuan maupun organisasi umumnya dihasilkan melalui pemikiran dari karyawan yang bekerja di dalamnya sehingga anggaran memiliki keterkaitan yang erat dengan karyawan di setiap organisasi. Karyawan sering kali membuat ruang dengan menaikkan perkiraan biaya maupun menurunkan perkiraan pemasukan secara berlebihan dalam upaya mengamankan kepastian akan terealisasinya anggaran yang diciptakan. Namun upaya menciptakan ruang yang dimaksud tergolong ke dalam perilaku tidak etis yang dikenal dengan istilah senjangan anggaran.

Andriati (2019) selaku Kabag Pemberitaan dan Publikasi KPK mengatakan bahwa kasus terkait masalah atau senjangan anggaran yang dapat dilakukan oleh karyawan dalam organisasi ini terjadi di semua sektor bisnis baik BUMN maupun swasta. Diansyah (2019) selaku Juru Bicara KPK juga menambahkan bahwa masalah terkait anggaran ini banyak terjadi di lingkungan pemerintah secara khusus industry perbankan. Prasetyo (2019) sebagai Jaksa Agung ikut menegaskan bahwa sebagian besar kasus penyelewengan dana yang terjadi terkait dengan BUMN yang ditanganinya umumnya berkaitan dengan masalah penyelewengan anggaran oleh karyawan maupun pejabat dari institusi yang terkait. Berdasarkan banyaknya kasus yang terjadi dapat dilihat bahwa salah satu faktor yang memengaruhi adanya senjangan anggaran adalah motivasi karyawan.

Faktor lain yang juga memengaruhi senjangan anggaran antara lain informasi asimetris. Kondisi ini terjadi ketika bawahan menyembunyikan satu atau beberapa informasi yang diperlukan sehingga manajemen tidak memiliki informasi yang cukup untuk mengukur kontribusi sebenarnya dari apa yang dilakukan atau dikerjakan oleh bawahannya. Langkah tepat yang mungkin dilakukan untuk mengurangi terjadinya situasi dimana informasi dinyatakan asimetris ialah dengan melaksanakan partisipasi penganggaran. Secara tidak langsung partisipasi dalam penganggaran memiliki keterkaitan juga dengan senjangan anggaran yang dipengaruhi oleh informasi asimetris.

Penelitian ini diharapkan dapat menganalisis beragam faktor yang menunjukkan pengaruh terhadap senjangan anggaran. Beragam faktor yang dimaksud antara lain penganggaran partisipatif, informasi asimetris, dan motivasi karyawan. Berdasarkan hal tersebut, penelitian ini akan 
menganalisis pengaruh antara penganggaran partisipatif terhadap senjangan anggaran terlebih dahulu. Dilanjutkan dengan analisis pengaruh informasi asimetris pada senjangan anggaran. Kemudian analisis pengaruh motivasi karyawan pada senjangan anggaran. Dengan dilakukannya penelitian ini diharapkan dapat memberikan masukan berupa kebijakan untuk perbaikan tata kelola dan kinerja untuk industri perbankan khususnya bank BUMN dilihat dari sisi penganggaran.

\section{KAJIAN PUSTAKA DAN \\ PENGEMBANGAN HIPOTESIS}

Senjangan anggaran dapat didefinisikan sebagai perbedaan yang dimunculkan dengan sengaja antara perkiraan atau estimasi anggaran yang diajukan dengan realisasi anggaran yang benar terjadi (Monden, 2000: 465). Slack anggaran juga dapat diartikan sebagai perbedaan antara estimasi pendapatan atau biaya yang diberikan oleh manajemen yang dilakukan dengan realistis dan pada dasarnya mampu dicapai (Shim et al, 2012: 25). Senjangan yang dimaksud pada dasarnya dapat terjadi jika terdapat informasi asimetris dalam suatu organisasi atau satuan unit (Dunk dan Nouri, 1998).
Informasi asimetris dapat diartikan sebagai konsep yang terjadi di dalam teori agensi ketika karyawan menyembunyikan informasi dari atasan sehingga atasan tidak mengetahui informasi yang dimaksud (Macintosh \& Quattrone, 2010: 68). Informasi asimetris sendiri merupakan fenomena umum yang memengaruhi, semua jenis perusahaan di berbagai negara pada tingkat yang berbeda (Bebczuc, 2003: 115). Faktor lain yang juga memengaruhi senjangan anggaran antara lain penganggaran partisipatif dan motivasi karyawan. Motivasi karyawan merupakan kemauan untuk mengerahkan upaya terbaik bagi tercapainya tujuan organisasi dan dicapai dengan menggunakan seluruh kemampuan yang dimiliki yang diimbangi dengan keinginan untuk mencapai tujuan pribadi (Gunkel, 2006: 21). Motivasi karyawan ini berbentuk dorongan yang diberikan pada karyawan agar performa atau kinerjanya mengalami peningkatan sehingga tujuan yang ingin dicapai organisasi dapat terpenuhi (Mutuku, 2018: 3).

Pengaruh Penganggaran Partisipatif Memiliki Pengaruh terhadap Senjangan Anggaran 
Penganggaran partisipatif dapat diartikan sebagai proses penganggaran dengan keterlibatan bawahan di dalam proses penyusunannya (Brink et al, 2018). Penganggaran partisipatif yang dilakukan pada dasarnya dapat memunculkan perpindahan informasi yang cukup efektif (Anthony \& Govindarajan, 2007: 391). Penganggaran partisipatif sendiri menunjukkan pengaruh negatif pada senjangan anggaran jika ditinjau dari penelitian yang dilakukan sebelumnya. Penelitian yang dilakukan oleh Syahrir (2017) menemukan bahwa penganggaran partisipatif memiliki pengaruh negative yang signifikan terhadap senjangan anggaran. Hal senada juga di diungkapkan oleh Kahar et al. (2016) yang menyatakan bahwa penganggaran partisipatif menunjukkan pengaruh negatif terhadap senjangan anggaran.

$H_{1}$ : Penganggaran Partisipatif Memiliki Pengaruh terhadap Senjangan Anggaran

\section{Pengaruh Informasi Asimetris Memiliki} Pengaruh terhadap Senjangan Anggaran

Senjangan anggaran dapat terjadi jika terdapat informasi asimetris dalam suatu organisasi atau satuan unit (Dunk dan Nouri, 1998). Hal ini menunjukkan bahwa informasi asimetris terindikasi memiliki pengaruh terhadap variabel senjangan anggaran. Pengaruh keduanya juga ditunjukkan melalui beberapa penelitian sebelumnya. Hidayani (2012) menyatakan dalam penelitiannya bahwa informasi asimetris memiliki pengaruh positif terhadap senjangan anggaran. Pernyataan ini juga didukung oleh Nurmayati et al. (2018) yang menyatakan bahwa informasi asimetris memiliki pengaruh positif terhadap senjangan anggaran.

\section{$\mathrm{H}_{2}$ : Informasi Asimetris Memiliki} Pengaruh terhadap Senjangan Anggaran

\section{Motivasi Karyawan Memiliki Pengaruh terhadap Senjangan Anggaran}

Motivasi karyawan merupakan kemauan untuk mengerahkan upaya terbaik bagi tercapainya tujuan organisasi dan dicapai dengan menggunakan seluruh kemampuan yang dimiliki yang diimbangi dengan keinginan untuk mencapai tujuan pribadi (Gunkel, 2006: 21). Motivasi karyawan ini memengaruhi setiap tindakan yang dilakukan oleh karyawan itu sendiri. Karsam (2015) melalui penelitiannya menyatakan bahwa motivasi karyawan memiliki pengaruh positif terhadap senjangan anggaran. Pernyataan ini didukung oleh Baerdermaeker dan Bruggeman (2015) yang menunjukkan bahwa 
motivasi karyawan secara khusus motivasi otonom menunjukkan adanya pengaruh terhadap senjangan anggaran.

\section{$H_{3}$ : Motivasi Karyawan Memiliki}

Pengaruh terhadap Senjangan Anggaran

\section{METODE PENELITIAN}

Objek penelitian pada dasarnya merupakan kumpulan dari beberapa elemen yang mewujud dalam bentuk orang maupun organisasi atau benda yang akan diteliti (Supranto, 2010:21). Objek penelitian pada penelitian ini antara lain: (1) senjangan anggaran, (2) penganggaran partisipatif, (3) informasi asimetris, dan (4) motivasi karyawan. Jenis penelitian yang terindikasi pada penelitian ini adalah penelitian berjenis kuantitatif.

Populasi merupakan keseluruhan dari kumpulan orang, kegiatan, maupun benda yang menarik untuk diteliti lebih lanjut oleh peneliti (Sekaran dan Bougie, 2013:240). Sampel merupakan kelompok tertentu yang diambil dari populasi untuk diteliti (Sekaran dan Bougie, 2013:241). Populasi pada penelitian ini adalah industri perbankan yang terdapat di Indonesia. Sementara itu, sampel yang diambil untuk penelitian ini adalah Bank Pemerintah (BUMN) yang terdapat di Negara Indonesia. Sampel yang diambil pada penelitian ini mencakup Bank Negara
Indonesia (Persero) Tbk., Bank Rakyat Indonesia (Persero) Tbk., Bank Tabungan Negara (Persero) Tbk., dan Bank Mandiri (Persero) Tbk.

Responden pada penelitian ini adalah manajer atau kepala pusat pertanggungjawaban dari masing - masing bank yang diteliti. Peneliti mengukur variabel penganggaran partisipatif melalui indikator yang diadopsi dari penelitian Milani (1975). Variabel informasi asimetris dapat diukur dengan menggunakan beberapa indikator yang dihasilkan oleh Dunk (1993) pada penelitian terdahulunya. Sementara itu, variabel motivasi karyawan diukur dengan menggunakan indikator yang dikembangkan oleh Warr et al (1979) yang telah dimodifikasi dan dihubungkan dengan anggaran oleh Dow et al (2015) dan telah banyak digunakan di dalam penelitian sebelumnya. Untuk variabel senjangan anggaran, diukur dengan menggunakan indikator yang dikembangkan oleh Van der Stede (2000).

Teknik pengumpulan data untuk penelitian ini adalah kuesioner. Kuesioner merupakan kumpulan pertanyaan yang diformulasikan untuk responden tertentu dimana alternatif jawaban mereka akan dicatat (Sekaran dan Bougie, 2013:147). 
Kuesioner di sebar melalui masing - masing pusat pertanggungjawaban dan kemudian diisi oleh manajer pusat pertanggungjawaban tersebut. Pertanyaan kuesioner yang digunakan pada penelitian ini bersifat pertanyaan tertutup. Penelitian ini menggunakan skala pengukuran ordinal pada setiap pertanyaan yang disajikan. Skala pengukuran ordinal merupakan skala pengukuran yang tidak menunjukkan seberapa besar perbedaan antarvariabel melainkan hanya perbedaan kategori (Sekaran dan Bougie, 2013:213).

Metode analisis untuk penelitian ini antara lain PLS 'Partial Least Square'. Alasan penggunaan metode PLS untuk menganalisis data yang dikumpulkan antara lain jumlah sampel yang diambil (Hair et al, 2014). Pengambilan sampel yang dilakukan pada penelitian ini berjumlah $<100$ hotel. Hal ini menunjukkan bahwa penelitian ini memenuhi kriteria penggunaan metode PLS dimana jumlah sampel harus lebih kecil dari 100. Berikut ini adalah konstruksi diagram jalur dari indikator - indikator atas variabel yang diteliti.

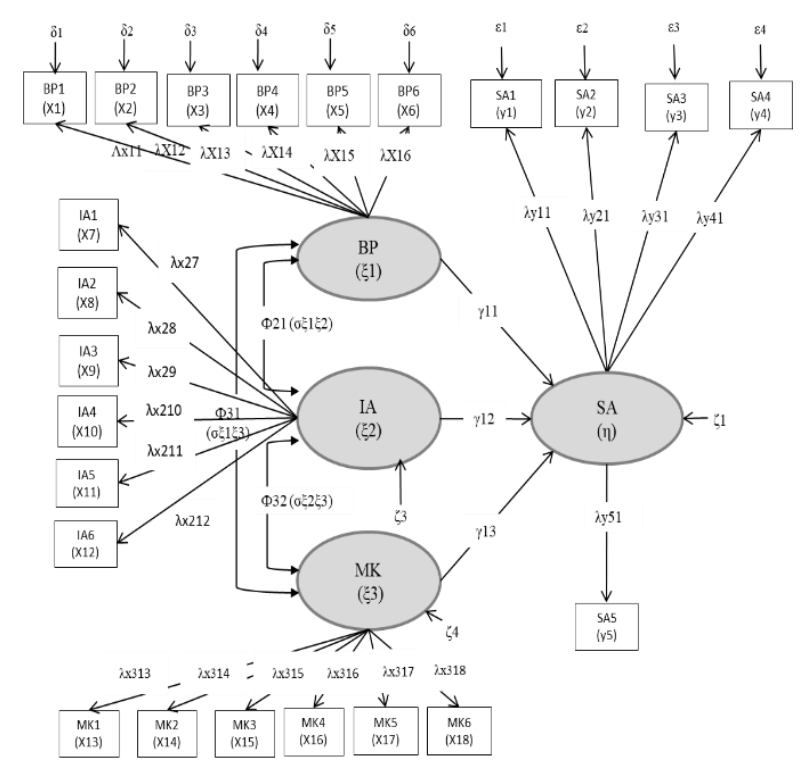

Theoretical Framework

Keterangan: $S A=$ Senjangan Anggaran $; I A=$ Informasi Asimetris; $M K=$ Motivasi Karyawan; $B P=$ Penganggaran Partisipatif

\section{HASIL DAN PEMBAHASAN}

Bentukan analisis yang diterapkan pada penelitian ini adalah analisis verifikatif. Analisis verifikatif pada penelitian ini dilakukan dengan melakukan evaluasi model pengukuran (outer model), evaluasi model structural (inner model), dan uji signifikansi (uji hipotesis). Evaluasi model pengukuran yang dilakukan pada penelitian ini terdiri dari dua tahap yaitu uji validitas indikator dan uji reliabilitas variabel. Evaluasi model structural akan dilakukan dengan menganalisis nilai Rsquare. Sementara itu, uji hipotesis akan dilakukan dengan menganalisis nilai t- 
statistik untuk menguji H0 dari setiap hipotesis penelitian yang dimiliki.

Uji validitas untuk setiap indikator dan uji reliabilitas untuk setiap variabel pada penelitian ini dilakukan dengan mengukur nilai loading factors dan composite reliability. Di bawah ini merupakan nilai loading factors dari setiap indikator yang diteliti.

Nilai Loading Factors Indikator Penelitian

\begin{tabular}{|c|c|c|c|}
\hline Variabel & Indikator & $\begin{array}{c}\text { Loading } \\
\text { Factors }\end{array}$ & Validitas \\
\hline \multirow{4}{*}{ SA } & SA1 & 0.692 & Valid \\
\cline { 2 - 4 } & SA2 & 0.845 & Valid \\
\cline { 2 - 4 } & SA3 & 0.837 & Valid \\
\cline { 2 - 4 } & SA4 & 0.854 & Valid \\
\cline { 2 - 4 } & SA5 & 0.788 & Valid \\
\hline \multirow{5}{*}{ BP } & BP1 & 0.533 & Valid \\
\cline { 2 - 4 } & BP2 & 0.023 & Invalid \\
\cline { 2 - 4 } & BP3 & 0.586 & Valid \\
\cline { 2 - 4 } & BP4 & 0.523 & Valid \\
\cline { 2 - 4 } & BP5 & 0.349 & Invalid \\
\cline { 2 - 4 } & BP6 & 0.709 & Valid \\
\hline \multirow{5}{*}{ IA } & IA1 & 0.501 & Valid \\
\cline { 2 - 4 } & IA2 & 0.146 & Invalid \\
\cline { 2 - 4 } & IA3 & 0.568 & Valid \\
\cline { 2 - 4 } & IA4 & 0.611 & Valid \\
\cline { 2 - 4 } & IA5 & 0.289 & Invalid \\
\cline { 2 - 4 } & IA6 & 0.755 & Valid \\
\hline \multirow{4}{*}{ MK } & MK1 & 0.335 & Invalid \\
\cline { 2 - 4 } & MK2 & 0.698 & Valid \\
\cline { 2 - 4 } & MK3 & 0.576 & Valid \\
\cline { 2 - 4 } & MK4 & 0.025 & Invalid \\
\cline { 2 - 4 } & MK5 & 0.649 & Valid \\
\cline { 2 - 4 } & MK6 & 0.530 & Valid \\
\hline
\end{tabular}

Sumber: Olahan Peneliti

Keterangan: $S A=$ Senjangan Anggaran; $I A=$

Informasi Asimetris; $M K=$ Motivasi Karyawan; $B P=$ Penganggaran Partisipatif
Hasil penilaian loading factors di atas menunjukkan bahwa terdapat enam indikator yang tidak valid. Indikator tersebut antara lain BP2, BP5, IA1, IA5, MK1, dan MK4. Keenam indikator ini akan dihilangkan untuk memastikan validitas penelitian yang dilakukan sehingga indikator yang digunakan untuk penelitian ini pada tahap selanjutnya tersisa 17 indikator. Sementara itu, berikut ini merupakan nilai dari pengukuran atas composite reliability dari setiap variabel yang ada dan diteliti.

Uji Reliaiblitas Variabel Laten

\begin{tabular}{|c|c|c|}
\hline Variabel & $\begin{array}{c}\text { Composite } \\
\text { Reliability }\end{array}$ & Reliabilitas \\
\hline $\begin{array}{c}\text { Senjangan } \\
\text { Anggaran }\end{array}$ & 0.902 & Reliabel \\
\hline $\begin{array}{c}\text { Penganggaran } \\
\text { Partisipatif }\end{array}$ & 0.693 & Reliabel \\
\hline $\begin{array}{c}\text { Informasi } \\
\text { Asimetris }\end{array}$ & 0.702 & Reliabel \\
\hline $\begin{array}{c}\text { Motivasi } \\
\text { Karyawan }\end{array}$ & 0.691 & Reliabel \\
\hline
\end{tabular}

Sumber: Olahan Peneliti

Hasil uji keandalan atau reliabilitas tersebut di atas menunjukkan bahwa keempat variabel yang diteliti pada penelitian ini mempunyai tingkat reliabilitas yang cenderung baik.

Evaluasi untuk model structural yang diterapkan pada penelitian ini akan dilakukan dengan menganalisis nilai R-square dari variabel endogen yang dimiliki. Variabel endogen yang dimaksud pada penelitian ini 
adalah variabel senjangan anggaran (Y). Variabel senjangan anggaran pada penelitian ini memiliki nilai R-Square 0.4040 yang artinya nilai $0.40<\mathrm{R}$-square $<0.70$. Hasil perhitungan tersebut menunjukkan bahwa predictor model senjangan anggaran pada dasarnya baik dalam menjelaskan varians. Dengan kata lain, model ini tergolong ke dalam bentuk permodelan yang kuat.

Hasil uji hipotesis penelitian ini adalah sebagai berikut.

\section{Uji Hipotesis}

\begin{tabular}{|l|c|c|}
\hline \multicolumn{1}{|c|}{$\begin{array}{c}\text { Hubungan } \\
\text { Antarvariabel }\end{array}$} & t-statistics & $\begin{array}{c}\text { Hasil } \\
\text { Analisis }\end{array}$ \\
\hline $\begin{array}{l}\text { Penganggaran } \\
\text { Partisipatif } \\
\text {->Senjangan } \\
\text { Anggaran }\end{array}$ & 0.474 & $\begin{array}{c}\text { Tidak } \\
\text { memiliki } \\
\text { pengaruh }\end{array}$ \\
\hline $\begin{array}{l}\text { Informasi } \\
\text { Asimetris } \\
\text {->Senjangan } \\
\text { Anggaran }\end{array}$ & 2.264 & $\begin{array}{l}\text { Memiliki } \\
\text { pengaruh }\end{array}$ \\
\hline $\begin{array}{l}\text { Motivasi } \\
\text { Karyawan } \\
\text {->Senjangan } \\
\text { Anggaran }\end{array}$ & 2.721 & $\begin{array}{l}\text { Memiliki } \\
\text { pengaruh }\end{array}$ \\
\hline
\end{tabular}

Sumber: Olahan Peneliti

\section{Pengujian hipotesis variabel penganggaran partisipatif $\left(X_{1}\right)$ terhadap variabel senjangan anggaran $(Y)$}

Penganggaran partisipatif

dihipotesiskan memiliki pengaruh atas variabel senjangan anggaran untuk penelitian ini. Uji hipotesis statistik yang dimaksud adalah sebagai berikut:
$H_{01}: \gamma_{\mathbf{1 1}}=0$, Penganggaran partisipatif tidak memiliki pengaruh terhadap senjangan anggaran.

$H_{11}: \gamma_{\mathbf{1 1}} \neq 0, \quad$ Penganggaran partisipatif memiliki pengaruh terhadap senjangan anggaran.

Statistik uji yang digunakan pada penelitian ini adalah menolak $H_{0}$ apabila $\mathrm{t}$ hitung $>\mathrm{t}$ tabel. Hasil uji statistik untuk nilai t hitung pada uji hipotesis variabel penganggaran partisipatif terhadap variabel senjangan anggaran yang berkualitas menghasilkan angka $0.474<\mathrm{t}$ tabel (1.995). Nilai ini menunjukkan bahwa $H_{01}$ pada penelitian ini diterima sehingga variabel laten yang merupakan variabel penganggaran partisipatif dengan indikator - indikatornya dinyatakan tidak memiliki pengaruh terhadap variabel laten lainnya yaitu variabel senjangan anggaran.

Penganggaran partisipatif sendiri pada dasarnya merupakan suatu konsep yang berkaitan dengan senjangan anggaran. Hasil penelitian ini menunjukkan bahwa keberadaan variabel penganggaran partisipatif tidak memiliki pengaruh yang signifikan terhadap keberadaan variabel senjangan anggaran. Hasil penelitian ini pada dasarnya didukung beberapa penelitian 
sebelumnya yang pernah dilakukan oleh Syahrir (2017) maupun Kahar et al. (2016).

\section{Pengaruh informasi asimetris terhadap variabel senjangan anggaran}

Informasi asimetris dihipotesiskan memiliki pengaruh terhadap variabel senjangan anggaran pada penelitian ini. Uji hipotesis statistik yang dimaksud adalah sebagai berikut:

$H_{02}: \gamma_{12}=0, \quad$ informasi asimetris tidak memiliki pengaruh terhadap senjangan anggaran.

$H_{12}: \gamma_{\mathbf{1 2}} \neq 0$, informasi asimetris memiliki pengaruh terhadap senjangan anggaran.

Statistik uji yang digunakan adalah menolak $H_{0}$ apabila $\mathrm{t}$ hitung $>\mathrm{t}$ tabel. Hasil uji statistik untuk nilai t hitung pada uji hipotesis untuk variabel informasi asimetris terhadap variabel senjangan anggaran yang berkualitas menghasilkan angka 2.264>t tabel (1.995). Hal ini menunjukkan bahwa $H_{02}$ pada penelitian ini ditolak sehingga keberadaan variabel laten yang merupakan variabel informasi asimetris dengan indikator indikatornya dinyatakan memiliki pengaruh terhadap keberadaan variabel laten lainnya yaitu variabel senjangan anggaran.

Pada dasarnya senjangan anggaran dapat terjadi jika terdapat informasi asimetris dalam suatu organisasi atau satuan unit (Dunk dan Nouri, 1998). Hasil penelitian ini membuktikan pernyataan Dunk dan Nouri (1998) tersebut bahwa terdapat hubungan antara informasi asimetris dengan budgetary slack. Hasil penelitian yang menunjukkan pengaruh antara budgetary slack dan informasi asimetris dengan ini pun didukung oleh beberapa penelitian sebelumnya. Penelitian sebelumnya tersebut merupakan penelitian yang dilakukan oleh Hidayani (2012) dan Nurmayati et al. (2018).

\section{Pengaruh motivasi karyawan terhadap variabel senjangan anggaran}

Motivasi karyawan dihipotesiskan memiliki pengaruh terhadap variabel senjangan anggaran pada penelitian ini. Uji hipotesis statistik yang dimaksud adalah sebagai berikut:

$H_{03}: \gamma_{13}=0$, motivasi karyawan tidak berpengaruh terhadap senjangan anggaran.

$H_{13}: \gamma_{13} \neq 0$, motivasi karyawan berpengaruh terhadap senjangan anggaran.

Statistik uji yang digunakan adalah menolak $H_{0}$ apabila $\mathrm{t}$ hitung $>\mathrm{t}$ tabel. Hasil uji statistik untuk nilai t hitung pada uji hipotesis variabel motivasi karyawan terhadap variabel senjangan anggaran yang berkualitas menghasilkan angka 2.721>t tabel (1.995). 
Hal ini menunjukkan bahwa $H_{03}$ pada penelitian ini ditolak sehingga variabel laten motivasi karyawan dengan indikator indikatornya dinyatakan berpengaruh terhadap variabel laten senjangan anggaran.

\section{Kesimpulan}

Berdasarkan hasil akhir dari penelitian yang dilakukan secara menyeluruh serta pembahasan yang dikemukakan pada bagian sebelumnya, simpulan dari penelitian ini adalah variabel penganggaran partisipatif dinyatakan tidak berpengaruh terhadap variabel senjangan anggaran. Sementara itu, variabel informasi asimetris dan variabel motivasi karyawan masing - masing dinyatakan berpengaruh terhadap variabel senjangan anggaran.

\section{Saran}

Adapun saran keilmuan yang dapat dikembangkan sejalan dengan hasil penelitian ini berkaitan penambahan variabel. Penambahan yang dimaksud berhubungan dengan penggunaan variabel sikap sebagai variabel moderasi untuk menghubungkan variabel independen motivasi karyawan dengan senjangan anggaran. Variabel sikap ini dapat dipertimbangkan karena tendensi atau kecenderungan yang nampak dari masing - masing karyawan dalam melakukan setiap tindakan didasari oleh cara bersikap. Tentunya variabel ini dapat memperkuat penjelasan terkait pengaruh antara motivasi terhadap adanya senjangan anggaran dalam sebuah organisasi.

Sementara itu, hasil akhir dari penelitian yang dilakukan ini juga dapat dimanfaatkan oleh BUMN khususnya sektor perbankan untuk dijadikan dasar atau referensi berkaitan dengan upaya peningkatan kualitas SDM yang dimiliki dengan mempertimbangkan beberapa faktor. Faktor yang dimaksud diantaranya pengembangan kualitas SDM yang dapat dilakukan dengan cara pemberian sarana pelatihan dalam membangun sikap mental kerja yang sehat. Hal ini diharapkan dapat mengendalikan maupun mencegah tendensi dari masing masing karyawan yang bekerja pada perusahaan terkait dalam mengupayakan sesuatu yang bertentangan dengan budaya maupun nilai - nilai yang dibangun perusahaan.

\section{Daftar Pustaka}

Anthony, R. N., \& Govindarajan, V. (2007). Management Control Systems. Singapore: McGraw-Hill Education (Asia). 
Bebczuc, R. (2003). Asymmetric Information in Financial Markets . Cambridge: Cambridge University Press.

Baerdemaeker, J. d., \& Bruggeman, W. (2015). The Impact of Participation Strategic Planning on Managers' Creation of Budgetary Slack: The Mediating Role of Autonomous Motivation and Affective Organizational Commitment. Management Accounting Research, xxx-xxx.

Brink, A. G., Coats, J. G., \& Rankin, F. W. (2018). Who's the boss? The economic and behavioral implications of various characterizations of the superior in participative budgeting research. Journal of Accounting Literature.

Cindy. (2019). Alex Noerdin Memenuhi Panggilan Kejaksaan Agung. Retrieved from Medcom: https://www.medcom.id/nasional/hukum/PNg L6zPb-alex-noerdin-memenuhi-panggilankejaksaan-agung

Dow, K. E., Watson, M. W., Greenberg, P. S., \& Greenberg, R. H. (2012). Understanding Participation: Situational Participation, Intrinsic Involvement, and Influences. Advances in Management Accounting.

Dunk, A. S. (1993). The Effect of Budget Emphasis and Information Asymmetry on The relation Between Budgetary Participation and Slack. The Accounting Review.

Fajar, T. (2019). Sri Mulyani: Kemenkeu akan Jaga APBN 2020 Tetap Sehat. Retrieved from Okezone: https://economy.okezone.com/read/2019/08/2 1/20/2094697/sri-mulyani-kemenkeu-akanjaga-apbn-2020-tetap-sehat

Gunkel, M. (2006). Country-Compatible Incentive Design: A Comparision of Employees' Performance Reward Preferences in Germany and USA. Wiesbaden: Springer.

Hair, J., Hult, T., Ringle, C., \& Sarstedt, M. (2014). A Primer On Partial Least Squares Structural Equation Modelling (PLS-SEM). California: SAGE.

Hidayani. (2012). The Effect Of Budgetary Participation, Asymmetry Information, Budget Emphasis And Comitment Organization To Budgetary Slack At SKPD Governmental Of Bengkulu City. The 13th Malaysia Indonesia Conference on Economics, Management and Accounting.

Junida, A. I. (2019). Roundup RAPBN 2020 Perkuat SDM, Lanjutkan Infrastruktur. Retrieved from Antaranews: https://www.antaranews.com/berita/1015886/ round-up-rapbn-2020-perkuat-sdm-lanjutkaninfrastruktur

Kahar, Rohman, \& Chariri. (2016). Participative Budgeting, Budgetary Slack, and Job Satisfaction in The Public Sector. The Journal of Applied Business Research.

Karsam. (2015). Effect of Budget Emphasis and Motivation on the Relationship between Participative Budgeting and Budgetary Slack and the Impact on the Managerial Performance (A Study on Yayasan Pendidikan Dan Koperasi in the Banten 
Province). Research Journal of Finance and Accounting.

Macintosh, N., \& Quattrone, P. (2010). Management Accounting and Control Systems: An Organizational and Sociological Approach. United Kingdom: John Wiley \& Sons Ltd.

Milani, K. (1975). The relationship of Participation in Budget Setting to Industrial Supervisor Performance and Attitudes: A Field Study. The Accounting Review.

Monden. (2000). Japanese Cost Management. London: Imperial College Press.

Mutuku, C. (2018). The Magic of Motivation in Business Organizations. Berlin: Grin.

Novelino. (2019). KPK Periksa Komisaris Bank Jatim Terkait Kasus Suap Anggaran. Retrieved from $\quad \mathrm{CNN}$ Indonesia: https://www.cnnindonesia.com/nasional/2019 0712162718-12-411634/kpk-periksa-

komisaris-bank-jatim-terkait-kasus-suapanggaran

Nurmayati, Akram, \& Yasin. (2018). Effect of Participatory Budget, Information Asymmetry, Organization Commitment, Budget Emphasis and Individual Capacity Toward Budgetary Slack in Local Government in Central Lombok Indonesia. International Journal of Economics, Commerce and Management.

Sekaran, \& Bougie. (2013). Research Methods for Business: A Skill Building Approach 6th Edition. United Kingdom: Wiley.
Shim, J. K., Siegel, J. G., \& Shim, A. I. (2012). Budgeting Basics and Beyond (4th ed.). USA: John Wiley \& Sons, Inc.

Suparman, F. (2019, Juni 25). KPK dan OECD Bahas Pencegahan Korupsi di Sektor Swasta. Retrieved from Berita Satu: https://www.beritasatu.com/nasional/561073/ kpk-dan-oecd-bahas-pencegahan-korupsi-disektor-swasta

Supranto. (2010). Statistik Teori dan Aplikasi. Jakarta: UI Press.

Syahrir. (2017). Pengaruh Penganggaran Partisipatif Terhadap Budget Slack dengan Sikap sebagai Variabel Moderating. Jurnal InFestasi.

Van der Stede, W. A. (2000). The Relationship between Two Consequences of Budgetary Controls: Budgetary Slack Creation and Managerial Short-Term Orientation. Accounting Organizations and Society.

Warr, P., Cook, J., \& Wall, T. (1979, Juni). Scales for the Measurement of Some Work Attitudes and Aspects of Psychological Well-Being. Journal of Occupational Psychology.

Wicaksono, A. (2019, Februari 12). Kemendagri: Larangan PNS Rapat di Hotel Informasi Sesat. Retrieved from CNN Indonesia: https://www.cnnindonesia.com/nasional/2019 0212084019-20-368417/kemendagrilarangan-pns-rapat-di-hotel-informasi-sesat 